\title{
Two new Brazilian primates discovered, endangered
}

\author{
Stephen F. Ferrari and Helder L. Queiroz
}

Field studies at distant sites in Brazilian Amazonia have brought to light two new species of primate, the black-headed marmoset Callithrix nigriceps and the Ka'apor capuchin Cebus kaapori. Little is known about either species, although both appear to have small geographical ranges in regions with relatively high human densities and where habitat-degrading activities, such as logging and mining, have been intensifying over the past two decades. These discoveries highlight the uncertain nature of our understanding of primate diversity in what is probably the biologically richest nation on earth. They also underline the urgent need for more detailed information from many areas, especially southern

Amazonia, where habitat destruction is increasing.

Brazil is home to more species of primate than any other nation. In 1985 Mittermeier and Oates recorded 51 species, more than one-fifth of all living primate species. Eighteen of these are endemic to Brazil. While Brazil's tropical forest is more than three times as extensive as that of any other country, many of these species, especially those endemic to the Atlantic forest, such as muriquis, lion tamarins and buffy-headed marmosets, are highly endangered, primarily through the widespread and largely uncontrolled destruction of their native habitats (Mittermeier et al., 1982; Ferrari and Mendes, 1991).

Since Mittermeier and Oates's review (1985), taxonomic revisions, such as those of Hershkovitz (1990) and de Vivo (1991), have further increased the species list, in addition to identifying new endemics, such as the marmoset Callithrix intermedia and the titi monkey Callicebus hoffmannsi. While such revisions are based on the (sometimes contradictory, e.g. Hershkovitz, 1963, 1990) re-interpretation of existing specimens, new forms are still being discovered in the wild. Examples are the blackish squirrel monkey Saimiri vanzolinii from a relatively remote region of the upper Amazon basin (Ayres, 1985) and the blackhanded lion tamarin Leontopithecus caissara, which was discovered in the Atlantic forest of an island off the coast of the state of Paraná (Lorini and Persson, 1990). The site of this find is less than $200 \mathrm{~km}$ from São Paulo, the largest metropolis in South America with a human population approaching 20 million.

In 1992 no fewer than three new Brazilian taxa were described: the Maués marmoset Callithrix mauesi (Mittermeier et al., 1992), the black-headed marmoset Callithrix nigriceps (Ferrari and Lopes, 1992) and the Ka'apor capuchin Cebus kaapori (Queiroz, 1992). Like S. vanzolinii, Callithrix mauesi comes from a relatively inaccessible part of central Amazonia, an area that is reasonably well protected, at least for the time being, by its remoteness (Mittermeier et al., 1992). The discoveries of both Callithrix nigriceps and Cebus kaapori were almost as unexpected as that of L. caissara, coming as they did from the two most easily accessible and densely populated regions of Brazilian Amazonia. Unfortunately, the implications for the long-term survival of the new species are all too predictable.

\section{The black-headed marmoset Callithrix nigriceps}

Marmosets (Callithrix spp. and Cebuella pygmaea) are the smallest living monkeys (body 


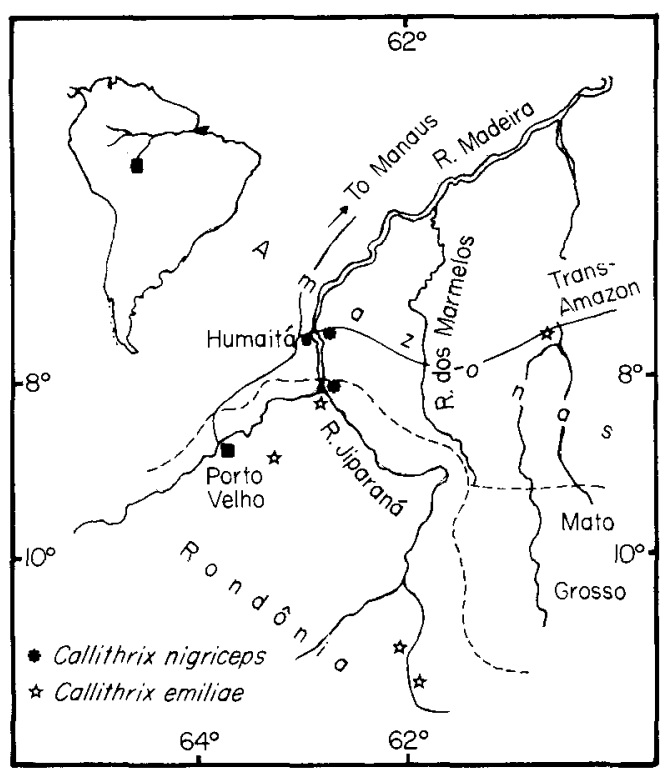

Figure 1. Known distribution of Callithrix nigriceps and Callithrix emiliae in western Brazilian Amazonia.

weight $0.1-0.4 \mathrm{~kg}$ ). Callithrix species can be separated into two groups by the presence or absence of tufts of hair in or around the ear. Bare-eared marmosets are restricted to the southern Amazon basin between the Madeira and Tocantins rivers (Hershkovitz, 1977; Ferrari and Lopes, 1990; de Vivo, 1991), extending as far south as the Pantanal and Chaco regions of western Brazil, eastern Bolivia and northern Paraguay. The bareeared Callithrix melanura is the only member of the genus found outside Brazil.

During a survey of primate distribution in the region of Humaitá on the Madeira river in western Brazilian Amazonia (Figure 1), Ferrari and Lopes (1992) found a previously undescribed form of bare-eared marmoset, which they designated Callithrix nigriceps, the blackheaded marmoset. Preliminary observations of $C$. nigriceps at two sites on the east bank of the Madeira (Figure 1) indicate that it is ecologically similar to other Callithrix marmosets (see Stevenson and Rylands, 1988). It was encountered relatively frequently in the lower or middle levels of secondary, disturbed and forest-edge habitats where, like other marmosets, its diet consisted of small fruits, plant gums and insects (Ferrari et al., 1993).

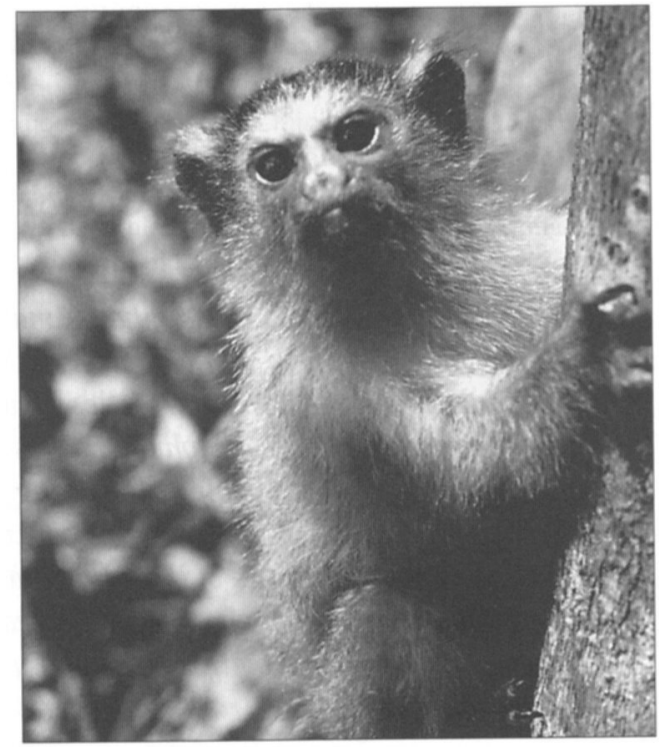

A juvenile female Cebus nigriceps from the Lago dos Reis, Amazonas state (Stephen F. Ferrari).

The western limit of the range of $C$. nigriceps appears to be the confluence of the Jiparaná and Madeira rivers (Figure 1); the eastern limit is unknown. Given the recorded distribution of Callithrix emiliae from the same region, C. nigriceps may occur no further east than the Rio dos Marmelos. If this is true, the geographical range of this species would be restricted to an area of little more than $10,000 \mathrm{sq} \mathrm{km}$.

This would be one of the smallest ranges for an Amazonian monkey and among the most precarious. Part of the range lies in the state of Rondonia, the major focus of human colonization and habitat destruction in western Brazilian Amazonia (Fearnside and Salati, 1985), and the rest in Amazonas state. The range is bisected by the Trans-Amazon highway, which crosses the asphalted Porto VelhoManaus highway at Humaitá. As elsewhere in Amazonia, roads have resulted in recent colonization (Fearnside and Ferreira, 1984). The region of the dos Marmelos river has been included among the top-priority areas for preservation in Amazonia (Wetterberg et al., 1976; Rylands and Mittermeier, 1982), although no reserve has yet been planned officially.

Logging operations and cattle ranching are already well established along the Trans- 


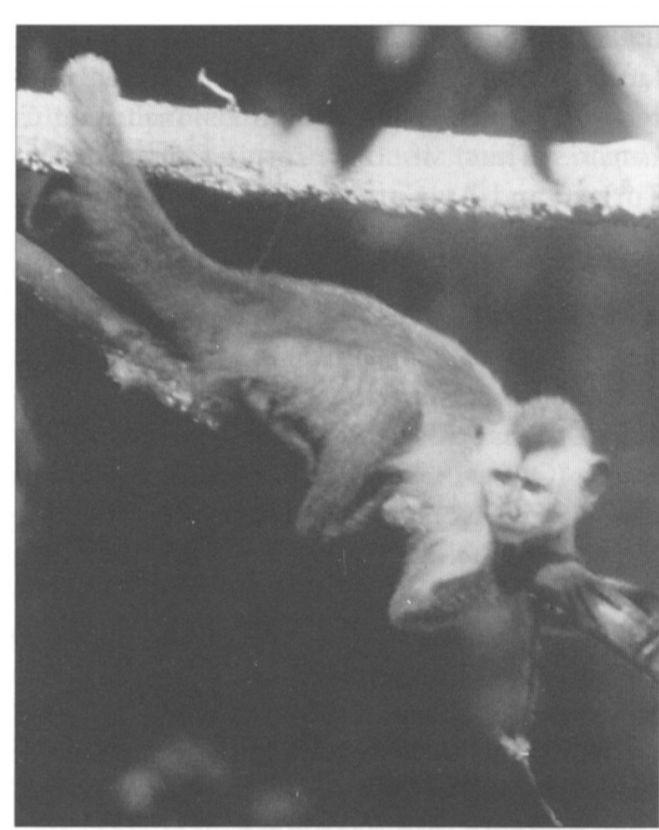

An adult female $C$. kaapori being raised as a pet by Guajá indians at the Awá Indian Post, CIR (Helder L. Queiroz).

Amazon east of Humaitá and in some areas habitat degradation is intense. Gold prospecting is a major stimulus for immigration into Rondônia, and prospectors are already exploring the Madeira River in the vicinity of Humaitá as well as lakes in the southern part of the $C$. nigriceps range. In addition to these problems, the Jiparaná has been earmarked for the construction of a hydro-electric power station, although the planned site is probably further south than the southern limit of $C$. nigriceps distribution.

\section{The Ka'apor capuchin Cebus kaapori}

Capuchins (Cebus spp.) are medium-sized monkeys $(2-3 \mathrm{~kg})$ with an ubiquitous distribution in the forested regions of the New World tropics (Freese and Oppenheimer, 1981). Like the marmosets, the genus can be divided into two groups on the basis of the presence or absence of tufts of hair, in this case on the top of the head. Cebus apella is the only tufted species, although it is also the most

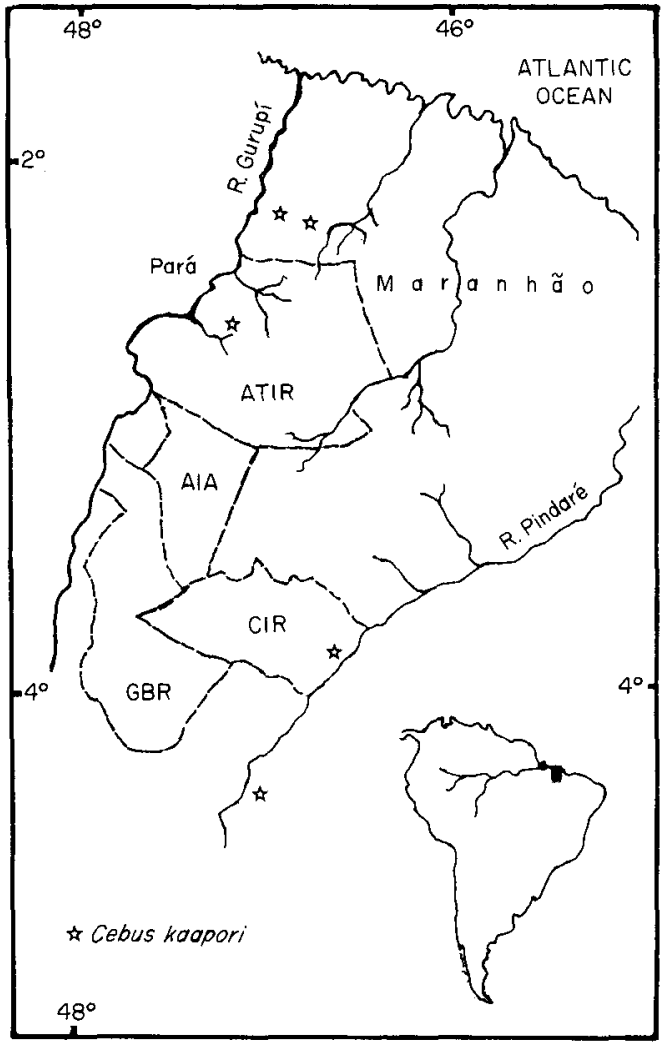

Figure 2. Known distribution of Cebus kaapori in eastern Brazilian Amazonia. Key to protected area: ATIR, Alto Turiaçu Indian Reservation; AIA, Awá Indian Area; CIR, Caru Indian Reservation; GBR, Gurupí Biological Reserve.

widespread of all New World monkey species. The untufted group originally consisted of three species: Cebus albifrons, C. capucinus and C. nigrivittatus (also known as C. olivaceus). The geographical distribution of these species is restricted to the north of the lower Amazon and the west of the Tapajós rivers.

During fieldwork with the Urubu-Ka'apor indians of western Maranhão state (Figure 2), Queiroz (1992) encountered a fourth species of untufted capuchin, which he named Cebus kaapori after the indians of the region. While sympatric with the tufted capuchin C. apella, the known present distribution of $C$. kaapori is apparently separated from those of the more closely related untufted capuchins by distances of more than $400 \mathrm{~km}$. Like other 
untufted capuchins, C. kaapori is less robust than $C$. apella, and apparently far less abundant in the wild, being perhaps more similar ecologically to C. nigrivittatus (Robinson and Janson, 1987; Baal et al., 1988) than to C. albifrons (Terborgh, 1983). Cebus kaapori is also closer geographically and morphologically to C. nigrivittatus, from which it may be derived (Queiroz, 1992).

The exact limits of the geographical distribution of Cebus kaapori have yet to be defined, although Queiroz (1992) proposed that it may now extend little further west than the Gurupi River, which forms the western border of Maranhão state (Figure 2). There is evidence (Goeldi and Hagmann, 1906), however, that C. kaapori was originally found much further west before the extensive deforestation of this region at the beginning of this century (Fearnside, 1984). The northern, eastern and southern limits of the species's range are more obscure, but may have been eroded by the ranching activities that have destroyed a large proportion of forested habitats in Amazonian Maranhão (Balée, 1988). This region has recently been included among the top priority areas for the preservation of Amazonian biodiversity (Kuliopulos, 1990).

The available information suggests that $C$. kaapori may be distributed over an area of at least $15,000 \mathrm{sq} \mathrm{km}$, which includes the 341,000 ha Gurupí Biological Reserve, the Awá Indian area $(65,000 \mathrm{ha})$, and the indian reservations of Alto Turiaçú $(530,524 \mathrm{ha})$ and Caru $(175,000$ ha). Theoretically then, C. kaapori habitat is better protected than that of the black-headed marmoset, although the Gurupí is little more than a 'paper reserve' (Oren, 1988), which, along with the indian reservations, has been subject to intolerable levels of illegal logging and squatting (Queiroz, 1992).

Given its size and habits, C. kaapori is particularly vulnerable to hunters, both indigenous and invasive (Redford and Robinson, 1987). Like C. nigrivittatus in Surinam (Baal et al., 1988), it may also be more vulnerable to hunting pressure than $C$. apella because of its relative rarity. Studies of the Guajá (Queiroz, in press) and Urubu-Ka'apor indians (Queiroz, unpubl. data) of the region never- theless indicate that their exploitation of local fauna is sustainable, given the low yield rate recorded for most game animals, including $C$. kaapori. Thus, if the Caru, Gurupí, Alto Turiaçú and Awá areas can be given the safeguards they are legally due, C. kaapori would receive a greater or lesser degree of protection within a contiguous area of almost $10,000 \mathrm{sq}$ $\mathrm{km}$.

The current situation in western Maranhão suggests that this will be unlikely in the near future (Oren, 1988), and if it does come in the long term, it may arrive too late for the Ka'apor capuchin. The ultimate effects of the Grande Carajás mining project alone, whose planned foundries would consume 2,500,000 tonnes of locally produced charcoal per annum, are frightening.

\section{New species, old problems}

The discovery of five new species in Brazil within the past decade underlines the precarious nature of our understanding of primate diversity in this crucially important tropical forest nation. The lack of information, from vast areas of the Amazon basin in particular, is a basic problem, but the absence of a general consensus on long-standing taxonomic questions (for example, Hershkovitz, 1963, 1977, 1984, 1990; Thorington, 1985; Mittermeier et al., 1988; de Vivo, 1991) is also of fundamental importance. The resolution of both these problems - the identification of existing primate populations and the definition of the taxonomic relations between them - will be imperative for the planning of effective conservation strategies (Rylands and Mittermeier, 1982; Mittermeier, 1986; Templeton, 1986).

Like the other new forms, both the blackheaded marmoset and the Ka'apor capuchin appear to have relatively small geographical ranges. As most regions of Brazil have been surveyed at least superficially, it seems likely that a restricted distribution will be typical of most, if not all, primate taxa yet to be encountered. As primates with small ranges and concomitantly small populations are generally more vulnerable to extinction than more cos- 
mopolitan forms (Mittermeier, 1986), it seems reasonable to assume that the potential difficulties of protecting primate diversity in Brazil will grow significantly as new taxa are identified.

The problem may not be a small one. Erwin (1988) and Nelson et al. (1990) have shown that the discovery of insect and plant species, respectively, in Amazonia may be directly related to sampling effort. To what extent this tendency might also apply to primates is unclear, but Callithrix, for example, is known from little more than 50 localities in Brazilian Amazonia, the majority of which are concentrated in southern Mato Grosso and the region of the lower Tapajós River (Hershkovitz, 1977; de Vivo, 1991; Mittermeier et al., 1992). Between these two extremes lie hundreds of thousands of square kilometres for which no information on the genus is available whatsoever. This includes much of Rondônia, northern Mato Grosso and southern Pará, the regions of Brazilian Amazonia that are suffering the highest rates of human expansion and habitat degradation (Fearnside and Salati, 1985). If more marmoset taxa do exist in this region, their preservation may depend on their being discovered before it is too late.

Together, Callithrix nigriceps and Cebus kaapori symbolize many of the problems of primate conservation in Brazil, a country whose tropical forests still cover an area almost 15 times that of Great Britain. Habitat degradation, inadequate reserve protection and hunting pressure are huge problems, but the paucity of our understanding of primate diversity in relation to the vastness of the country's forests may be equally important in the long term.

\section{Acknowledgments}

The studies reported here were supported by the John D. and Catherine T. MacArthur Foundation, the Noyes Foundation, the Science Research Council $(\mathrm{CNPq})$ of the Brazilian government and Wildlife Conservation International. We would like to thank Cida Lopes, Bill Balée, Fernando Nascimento, Dionísio Pimentel Neto, Cazuza Júnior and David Oren.
References

Ayres, J.M.C. 1985. On a new species of squirrel monkey, genus Saimiri, from Brazilian Amazonia (Primates, Cebidae). Pap. Avul. Zool., Univ. S. Paulo, 36, 147-164.

Baal, F.L.J., Mittermeier, R.A. and van Roosmalen, M.G.M. 1988. Primates and protected areas in Suriname. Oryx, 22, 7-14.

Balée, W.L. 1988. Ka'apor: forêt en otage dans l'état du Maranhão. Ethnies, 106-110.

Erwin, T.L. 1988. The tropical forest canopy: the heart of biotic diversity. In Biodiversity (ed. E. O. Wilson), pp. 123-129. National Academy Press, Washington DC.

Fearnside, P.M. 1984. A floresta vai acabar? Ciência Hoje, 10, 43-52.

Fearnside, P.M. and Ferreira, G. de L. 1984. Roads in Rondônia: highway construction and the farce of unprotected reserves in Brazil's Amazon forest. Environmental Conservation, 11, 358-360.

Fearnside, P.M. and Salati, E. 1985. Explosive deforestation in Rondônia, Brazil. Environmental Conservation, 12, 355-356.

Ferrari, S.F. and Lopes, M.A. 1990. A survey of primates in central Pará. Bol. Mus. Para. E. Goeldi. Zool. 6, 169-179.

Ferrari, S.F. and Lopes, M.A. 1992. A new species of marmoset, genus Callithrix Erxleben 1777 (Callitrichidae, Primates), from western Brazilian Amazonia. Goeldiana Zool. 12, 1-13.

Ferrari, S.F., Lopes, M.A. and Krause, E.A.K. 1993. Gut morphology of Callithrix nigriceps and Saguinus labiatus from western Brazilian Amazonia. Am. J. Phys. Anthropol. 90, 487-493.

Ferrari, S.F. and Mendes, S.L. 1991. Buffy-headed marmoset ten years on. Oryx, 25, 105-109.

Freese, C. and Oppenheimer, J.R. 1981. The capuchin monkeys, genus Cebus. In Ecology and Behavior of Neotropical Primates (eds A. F. CoimbraFilho and R. A. Mittermeier), Vol. 1. pp. 331-390. Academia Brasileira de Ciências, Rio de Janeiro.

Goeldi, E.A. and Hagmann, G. 1906. Prodromo de um catálogo crítico, comentado da coleçcão do Museu do Pará (1894-1903). Bol. Mus. Goeldi (Mus. Para.) Hist. Nat. Ethnogr. IV, 38-122..

Hershkovitz, P. 1963. A systematic and zoogeographical account of the monkeys of the genus Callicebus (Cebidae) of the Amazonas and Orinoco river basins. Mammalia, 27, 1-79.

Hershkovitz, P. 1977. Living New World Monkeys (Platyrrhini), Vol. 1. Chicago University Press, Chicago.

Hershkovitz, P. 1984. Taxonomy of squirrel monkeys genus Saimiri (Cebidae, Platyrrhini): a preliminary report with a description of a hitherto unnamed form. Am. J. Primatol. 7, 155-210.

Hershkovitz, P. 1990. Titis, new world monkeys of 
the genus Callicebus (Cebidae, Platyrrhini): a preliminary taxonomic review. Fieldiana Zool. 55.

Kuliopulos, H. 1990. Amazonian biodiversity. Science, 248, 1305.

Lorini, M.L. and Persson, V.G. 1990. Nova espécie de Leontopithecus Lesson 1840, do sul do Brasil (Primates, Callitrichidae). Bol. Mus. Nac. 338.

Mittermeier, R.A. 1986. Primate conservation priorities in the neotropical region. In Primates, The Road to Self-Sustaining Populations (ed. K. Benirschke), pp. 221-240. Springer Verlag, New York.

Mittermeier, R.A. and Oates, J.F. 1985. Primate diversity: the world's top countries. Primate Conserv. $5,41-48$.

Mittermeier, R.A., Coimbra-Filho, A.F., Constable, I.D., Rylands, A.B. and Valle, C.M.C. 1982. Conservation of primates in the Atlantic Forest of eastern Brazil. Int. Zoo Ybk. 22, 2-17.

Mittermeier, R.A., Rylands, A.B. and Coimbra-Filho, A.F. 1988. Systematics: species and subspecies an update. In Ecology and Behavior of Neotropical Primates (eds R. A. Mittermeier, A. B. Rylands, A. F. Coimbra-Filho and G. A. B. da Fonseca), Vol. 2. pp. 13-75. World Wildlife Fund-US, Washington DC.

Mittermeier, R.A., Schwarz, M. and Ayres, J.M.C. 1992. A new species of marmoset, genus Callithrix Erxleben, 1777 (Callitrichidae, Primates) from the Rio Maués region, state of Amazonas, central Brazilian Amazonia. Goeldiana Zool. 14, 1-17.

Nelson, B.W., Ferreira, C.A.C., da Silva, M.F. and Kawasaki, M.L. 1990. Endemism centres, refugia and botanical collection density in Brazilian Amazonia. Nature, 345, 715-719.

Oren, D.C. 1988. Uma reserva biológica para o Maranhão. Ciência Hoje, 44, 36-45.

Queiroz, H.L. 1992. A new species of capuchin monkey, genus Cebus Erxleben 1777 (Cebidae: Primates), from eastern Brazilian Amazonia. Goeldiana Zool. 15, 1-13.

Queiroz, H.L. In press. Os índios Guajá e os primatas da Amazônia maranhense: um caso de sustentabilidade de caça. In A Primatologia no Brasil 4 (eds M. E. Yamamoto and M. B. C. de Sousa). Sociedade Brasileira de Primatologia, Natal.
Redford, K. and Robinson, J.G. 1987. A game of choice: patterns of indian and colonist hunting in the Neotropics. Am. Anthropol. 89, 650-667.

Robinson, J.G. and Janson, C.H. 1987. Capuchins, squirrel monkeys and atelines: socioecological convergence with old world primates. In Primate Societies (eds B. B. Smuts, D. L. Cheney, R. W. Seyfarth, R. W. Wrangham and T. T. Struhsaker), pp. 69-82. Chicago University Press, Chicago.

Rylands, A.B. and Mittermeier, R.A. 1982 Parks, reserves and primate conservation in Brazilian Amazonia. Oryx, 17, 78-87.

Stevenson, M.F. and Rylands, A.B. 1988. The marmosets, genus Callithrix. In Ecology and Behavior of Neotropical Primates (eds R. A. Mittermeier, A. B. Rylands, A. F. Coimbra-Filho and G. A. B. da Fonseca), Vol. 2. pp. 131-222. World Wildlife Fund-US, Washington DC.

Templeton, A.R. 1986. Coadaptation and outbreeding depression. In Conservation Biology: the Science of Scarcity and Diversity (ed. M. E. Soulé), pp. 105-116. Sinauer Associates Inc., Sunderland Mass.

Terborgh, J. 1983. Five New World Primates: A Study in Comparative Ecology. Princeton University Press, Princeton NJ.

Thorington, R.W. 1985. The taxonomy and distribution of squirrel monkeys (Saimiri). In Handbook of Squirrel Monkey Research (eds R. A. Rosenblum and C. L. Coe), pp. 1-33. Plenum Press, New York.

de Vivo, M. 1991. Taxonomia de Callithrix Erxleben 1777 (Callitrichidae, Primates). Fundação Biodiversitas, Belo Horizonte, Brazil.

Wetterberg, G.B., Padua, M.T.J., Castro, C.S. de and Vasconcellos, J.M.C. 1976. Uma análise de prioridades em conservação da natureza na Amazônia. Projeto de Desenvolvimento e Pesquisa Florestal (PRODEPEF). PNUD/FAO/IBDF/BRA-45. Série Tecnica. 8. $62 \mathrm{pp}$.

Stephen F. Ferrari, Departamento de Génetica, Universidade Federal do Pará, Caixa Postal 8607, 66.075-150 Belém-PA, Brazil.

Helder L. Queiroz, Departamento de Zoologia, Museu Paraense Emilio Goeldi, Belém, Brazil. 